\title{
SANDWICH PANELS - BEHAVIOR IN FIRE BASED ON FIRE RESISTANCE TESTS
}

\author{
Paweł Roszkowski, Paweł Sulik \\ Building Research Institute, Fire Research Department, Warsaw, Poland
}

\begin{abstract}
Sandwich panel is the material that is easy and quickly to install. Basing on a great experience in the area of determination of the fire resistance class of construction building elements the authors describe the properties and behavior of building elements made of the sandwich panels exposed to fire. The article presents the results of fire resistance tests carried out in accordance with EN 1364-1 non-bearing walls made of sandwich panels with use of different cores.

The following parameters were analyzed: temperature rise on unexposed side (I - thermal insulation), integrity (E) depending on the orientations and on the width of the sandwich panels, deflection depending on the thickness of the boards. Conclusions were made on the base of the analysis from fire resistance tests.
\end{abstract}

Keywords: sandwich panel, fire resistance, (fire) insulation, (fire) integrity.

\section{INTRODUCTION}

Investors very often use the sandwich panels for the construction of storage facilities, sports halls and other public buildings, e.g. airport' hall, because of its ease of installation and short construction time. Sandwich panels consisting of metal facings and a combustible or noncombustible core are commonly used.

Sandwich panels in standard EN 14509 are defined as building product consisting of two metal faces positioned on either side of a core that is a thermally insulating material, which is firmly bonded to both faces so that the three components act compositely when under load.

The only way to verify the fire resistance of the walls are fire resistance tests. The method for determining the fire resistance of non-loadbearing walls is specified in standard EN 1364-1. In addition to the testing method, the standard defines the direct field of application of test results while extended application of results from fire resistance testes is given in standard EN 15254-5 and described in the article (Wróblewski, Borowy, 2012).

\section{FIRE RESISTANCE TEST}

\subsection{Test conditions and test specimen}

Test equipment and test conditions are given in standard EN 1363-1 and EN 1363-2.

In most of common solutions, the panel walls are used as the external elements of buildings. In these cases we can expected fire from interior or exterior side of the wall.

If fire is expected from exterior side, in fire resistance test should be used an external fire exposure curve (according to equation 1) or a standard temperature/time curve (according to equation2). If fire is expected from interior side, in fire resistance test should be used the standard temperature/time curve.

$\mathrm{T}=660[1-0,687 \exp (-0,32 \mathrm{t})-0,313 \exp (-3,8 \mathrm{t})]+20$

$\mathrm{T}=345 \log (8 \mathrm{t}+1)+20$

where

$\mathrm{T}$ is the mean furnace temperature in degrees Celsius;

$\mathrm{t}$ is the time form the start of the test in minutes.

The fire scenarios (curves) are shown in figure 1. 


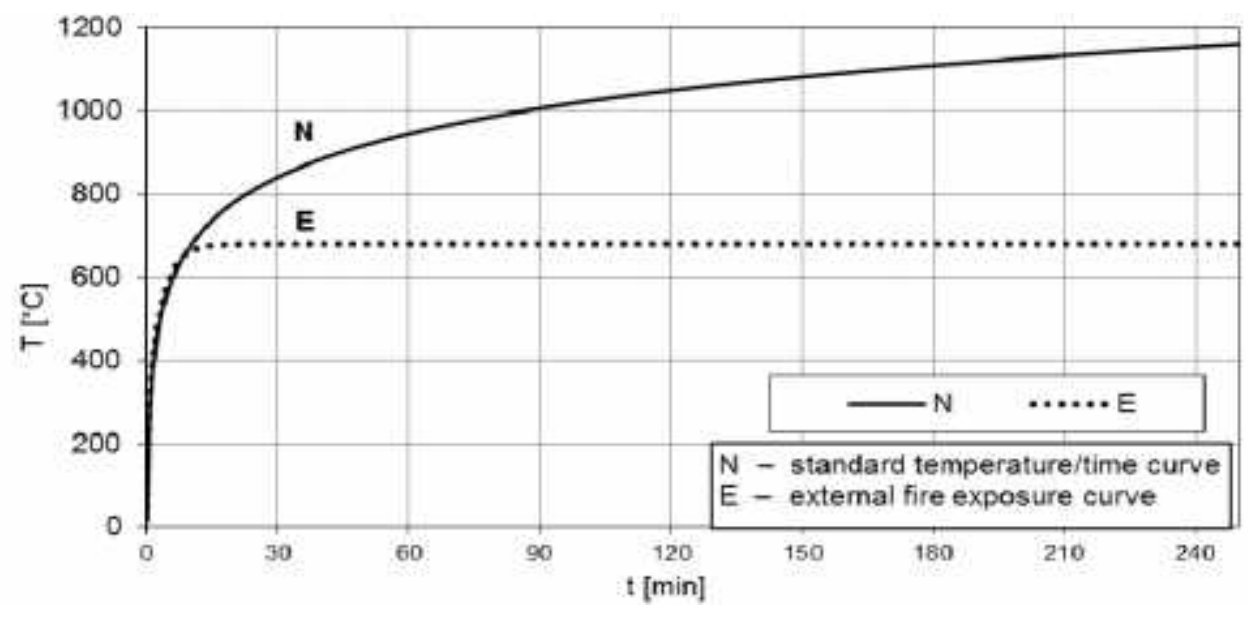

Fig. 1 Fire scenarios

There is possibility to determine two kind of orientation - vertical or horizontal. Scheme of panels orientation are shown in figure 2. Test specimens to fire resistance tests should have minimum dimensions of $3 \times 3 \mathrm{~m}$, one vertical edge (the vertical orientation of the panels) or one horizontal edge (the horizontal orientation of the panels) shall be left unrestrained and there shall be a gap of 25-50 mm (free edge).

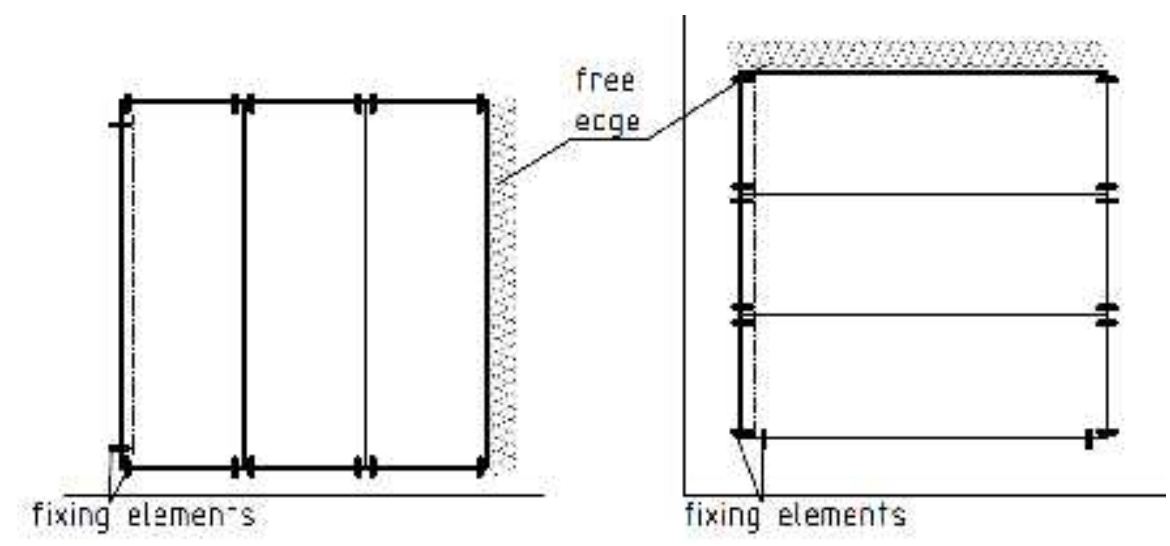

a) vertical orientation

b) horizontal orientation

Fig. 2 Scheme of wall panels orientation

The information about fields of direct application of the test results can be find in the standard EN 1364-1 and was also in the articles (Roszkowski, Sędłak, 2011) and (Sędłak, Roszkowski, 2012).

The following aspects (performance criteria) are determined during the fire resistance tests of nonloadbearing walls (according to standard EN 13501-2):

- Integrity separating function (E) - ability of the element of construction that has a separating function, to withstand fire exposure on one side only, without the transmission of fire to the unexposed side as a result of the passage of flames or hot gases;

- Thermal insulating separation function (I) - ability of the element of construction to withstand fire exposure on one side only, without the transmission of fire as a result of significant transfer of heat from the exposed side to the unexposed side;

- Radiation function (W) - ability of the element of construction to withstand fire exposure on one side only, so as to reduce the probability of the transmission of fire as a result of significant radiated heat either through the element or from its unexposed surface to adjacent materials.

Further very important aspect is the deflection of the test specimen (especially for field of application of test results). 
Typical location of the temperature and deflection measuring points on an exposed side are shown in fig. 3. For this purpose on unexposed side of test the deflection is measured.

where

$1-5$

6-14

A, B, C, D, E, F

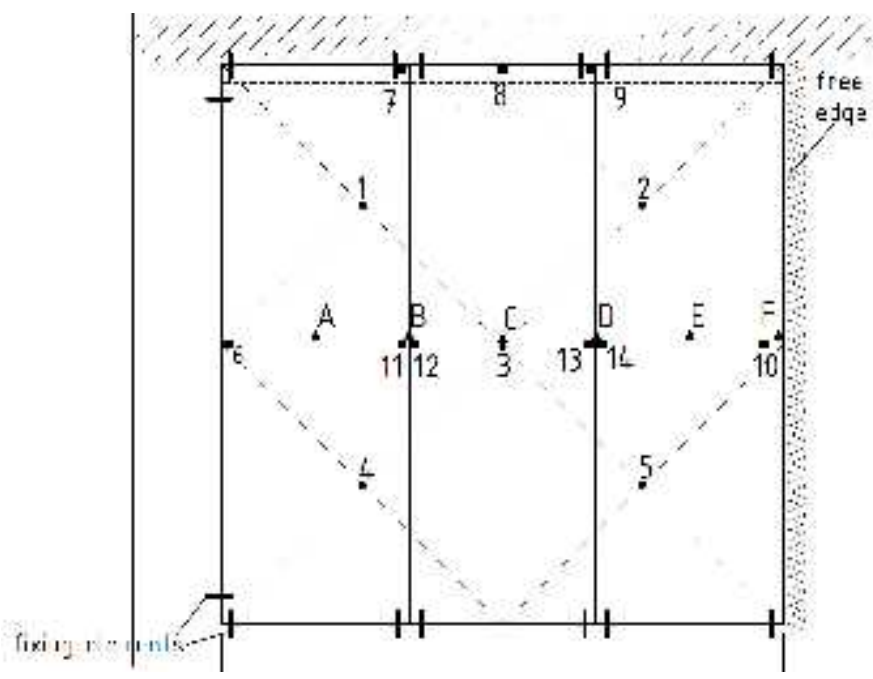

Fig. 3 Location of the temperature and deflection measuring points on unexposed surface

\subsection{Wall made of sandwich panels - general behaviour}

The typical behavior of wall made of sandwich panels exposed to fire according standard EN 15254-5 are shown in fig. 4.

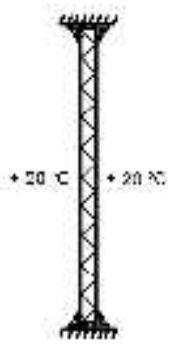

a.

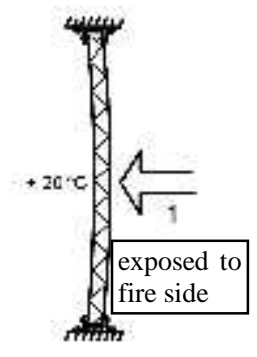

b.

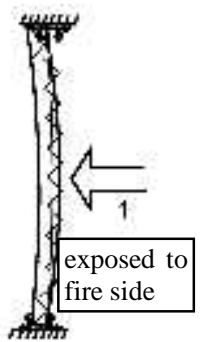

c.

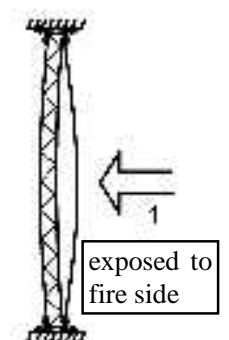

d.

Fig. 4 Typical behavior of wall made of sandwich panels exposed to fire according to EN 15254-5

Scheme (a) shows the wall before the fire test. Scheme (b) shows the wall at early stage of fire (from $0 \mathrm{~min}$ to $2 \mathrm{~min}$ ). Scheme (c) shows the wall at early stage of fire (from $2 \mathrm{~min}$ to $5 \mathrm{~min}$ ). The last scheme (d) shows the wall at the end of fire.

The above schemes shows the deformation processes. In the following points will be presented the results of tests for different cores (in the form of graphs and photographs from reprehensive tests).

All the fire tests presented in point 2.3, 2.4 and 2.5 were made in Fire Testing Laboratory of Building Research Institute in Pionki (POLAND).

\subsection{Panel walls with mineral wool (MW) core}

In the figure 5 are shown the graphs from the results. The results are presented from five tested specimens with different thicknesses, panels orientation and different density cores. The photographs in figure 6 show exemplary details from the fire tests. 


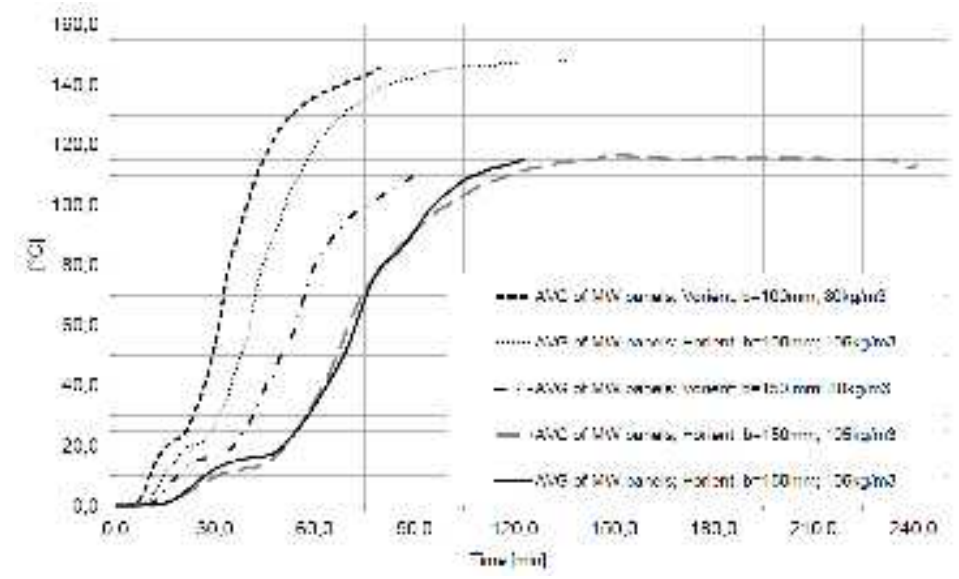

Fig. 5 Graph of temperature rises on unexposed side of panel walls with MW core (temperature measured with thermocouples for measuring the average and the maximum temperature rise)

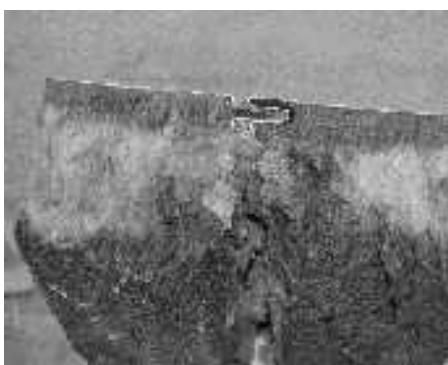

a) Cross section of MW core after $60 \mathrm{~min}$ esposed to fire

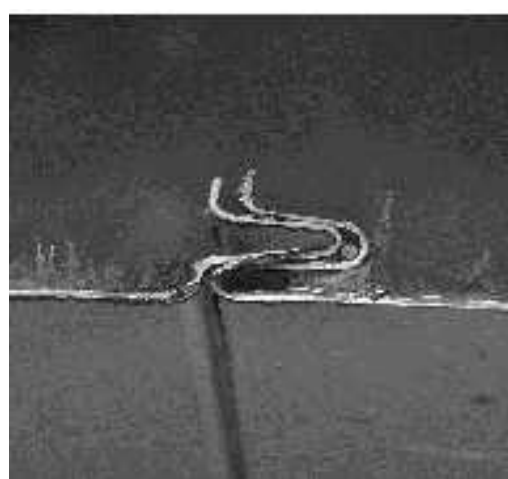

b) Clading from unexposed side of panel with MW core after the test

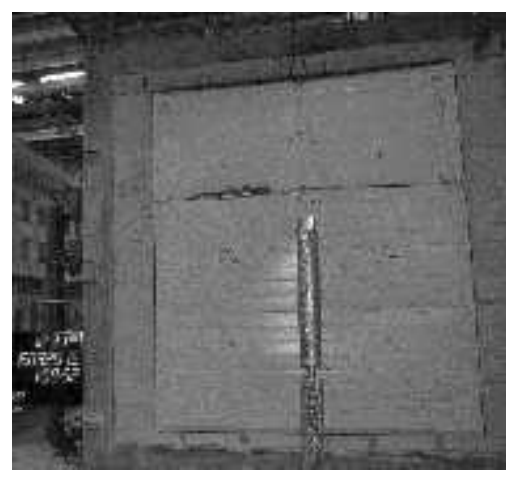

c) View of test specimen after 120 min exposed to fire

Fig. 6 Exemplary details of sandwich panel with mineral wool core after the fire resistance tests

\subsection{Panel walls with polyurethane foam (PIR) core}

The figure 7 shows the graphs from the results. The results are presented from two reprehensive tested specimens with different thicknesses. The photographs in figure 8 shows exemplary details from the fire tests.

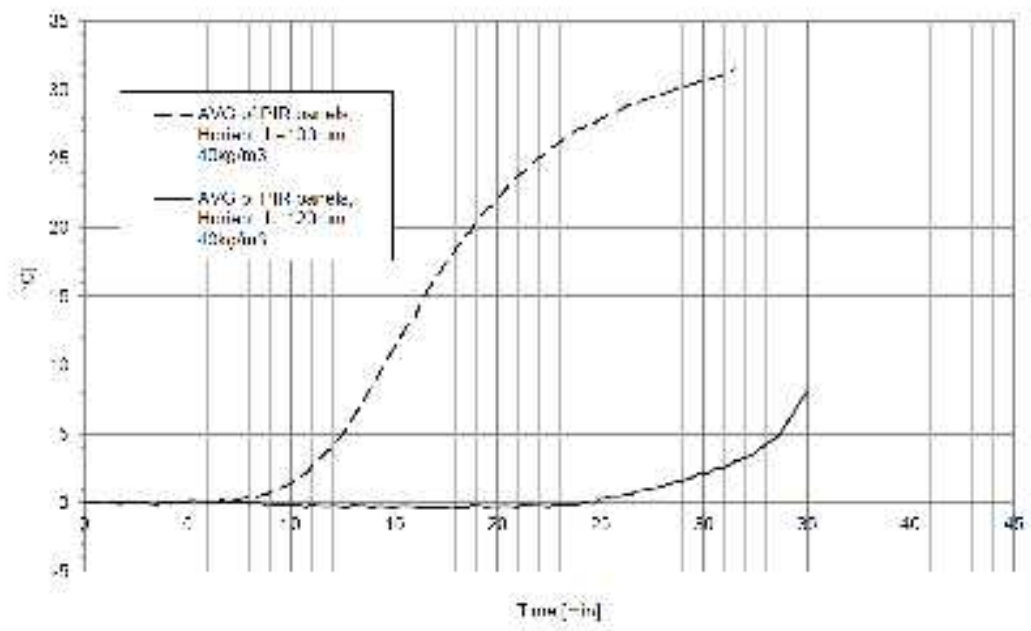

Fig. 7 Graph of temperature rises on unexposed side of panel walls with PIR core (temperature measured with thermocouples for measuring the average and the maximum temperature rise) 


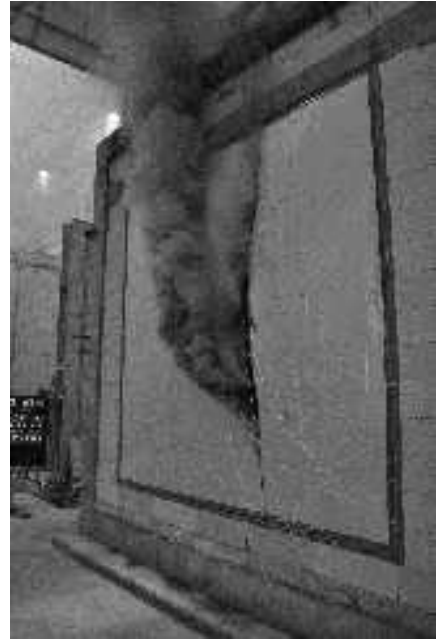

a) View of test speciment during the fire test

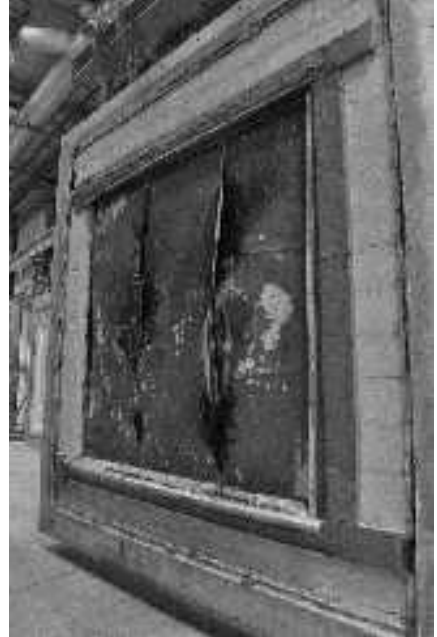

b) View of test speciment after the test - unexposed side

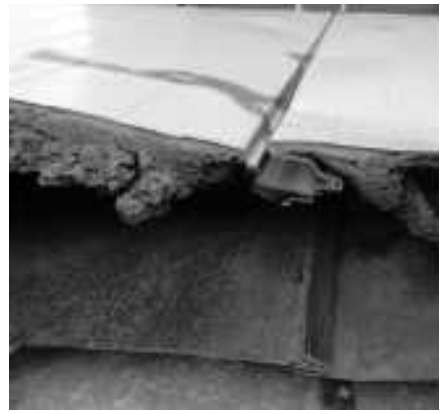

c) View of cross section of panels with PIR core

Fig. 8 Exemplary details of panel walls with PIR core during and after the fire resistance tests

\subsection{Panel walls with expanded polystyrene (EPS) core}

The figure 8 shows the graphs from the results. The results are presented from one tested specimens. The photographs in figure 10 shows exemplary details from the fire test.

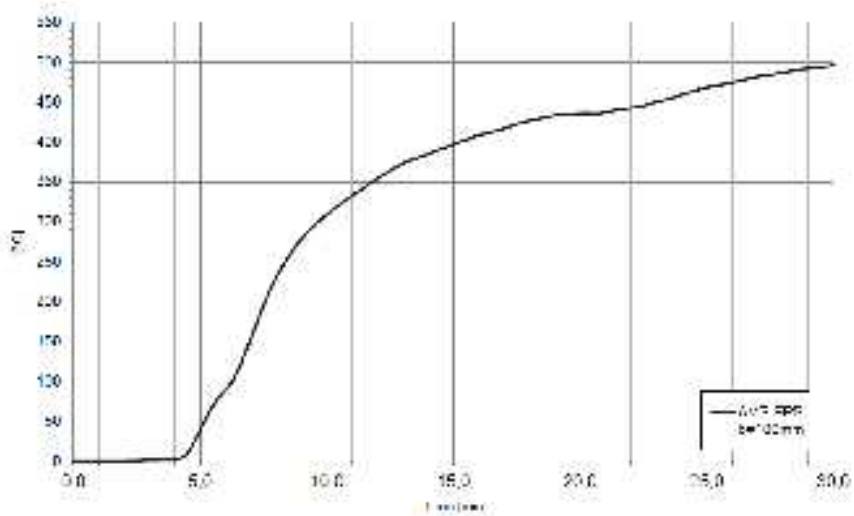

Fig. 9 Graph of temperature rise on unexposed side of panel wall with EPS core (temperature measured with thermocouples for measuring the average and the maximum temperature rise)

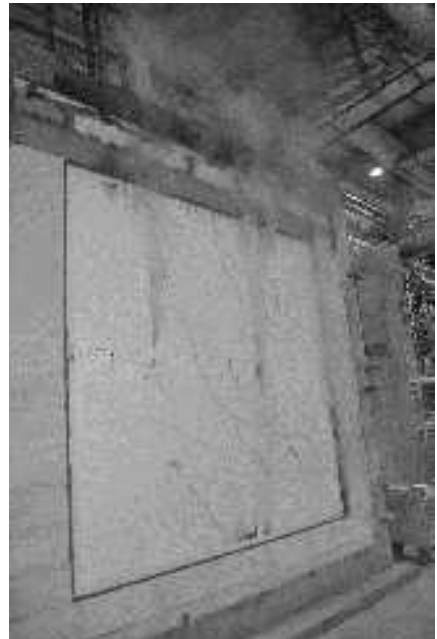

a) View of test speciment during the fire test - unexposed to fire side

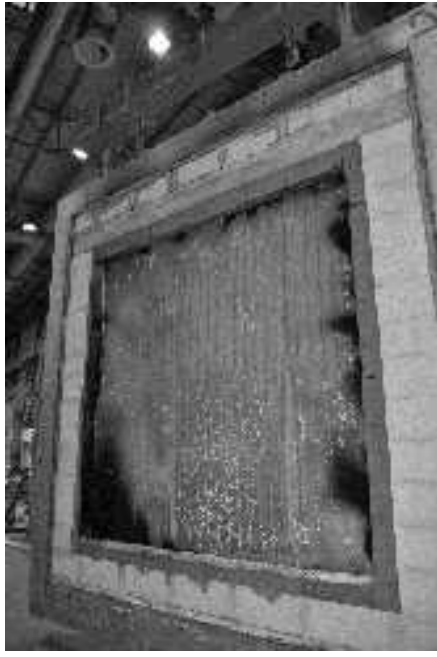

b) View of test speciment after the test exposed to fre side

Fig. 10 Details of panel wall with EPS core during and after the fire resistance tests 
Walls made of sandwich panels with the MW core have great insulation properties which confirm the results of fire resistance tests. The discrepancy of temperature rise of fire resistance tests' results (according to the measurement of the average temperature rise of the 5 thermocouples) depends on the core thickness and density and is significant:

- from $10^{\circ} \mathrm{C}$ to $50^{\circ} \mathrm{C}$ when the classification period is 30 minutes;

- from $15^{\circ} \mathrm{C}$ to $115^{\circ} \mathrm{C}$ when the classification period is 45 minutes;

- from $30^{\circ} \mathrm{C}$ to $135^{\circ} \mathrm{C}$ when the classification period is 60 minutes;

- from $110^{\circ} \mathrm{C}$ to $150^{\circ} \mathrm{C}$ when the classification period is 120 minutes.

The orientation of the panels with MW core does not affect the isolation (I) very much. Walls with such core show marginal deflection which is for sure a very useful feature while verification the integrity. The MW core reveals the signs of thermal degradation (smoldering) from the exposed side (see figure 6). While the fire resistance test last the long time (more than 180 minutes) also the metal facing is destroyed. The sandwich panel walls with MW core with the thickness of $100 \mathrm{~mm}$ and the density of $\min .80 \mathrm{~kg} / \mathrm{m}^{3}$ easily get the fire resistance class of EI 60. Using the panels with the thickness of $150 \mathrm{~mm}$, the density of the core of $105 \mathrm{~kg} / \mathrm{m}^{3}$ and the additional sealants with the fire proof mass allows to receive the fire resistance class of EI 240.

The walls made of sandwich panels with the PIR core also have great insulation properties which confirm the results of fire resistance tests. Temperature rise from unexposed side after 30 minutes of fire according to standard temperature/time curve (according to the measurement of the average temperature rise of the 5 thermocouples) usually does not exceeds $40^{\circ} \mathrm{C}$. The core during the fire resistance test is decomposed. Disconnection of the PIR core and exposed metal facing contributes to large deflection which leads to a sudden exceeding of the integrity criteria. The placement of the opening of the two adjacent metal sheet in most cases is in half of the facings width (see figure 8)

Moreover from a created crack is getting out a lot of toxic gases and sometime a flame is visible. The fire resistance class of the wall made of sandwich panels with PIR with thickness min. $100 \mathrm{~mm}$ in most cases is not higher than EI 30.

The walls made of sandwich panels with the EPS core compared to the MW core and PIR core have highly worse isolation ability. EPS core is fully consumed (thermally decomposed) during first 5-10 minutes of fire conditions. The temperature rise after 15 minutes of test in fire condition is $400^{\circ} \mathrm{C}$ and the temperature increase additional $100^{\circ} \mathrm{C}$ in the next 15 minutes. Because of the sudden and steadily process of the thermally decomposing of the EPS core, the deflection of the panels are not so significant (see figure 10). The walls made of sandwich panels with EPS core with the thickness of minimum $100 \mathrm{~mm}$ in most cases are classified not less than E 30.

\section{NORMATIVE REFERENCES}

EN 1364-1:1999 Fire resistance tests for non-loadbearing elements - Part 1: Walls

EN 1363-1:2012 Fire resistance tests - Part 1: General Requirements

EN 1363-2:2012 Fire resistance tests - Part 2: Alternative and additional procedures

EN 15254-5:2009 Extended application of results from fire resistance testes - Non-loadbearing walls - Pars 5: Metal sandwich panel construction

EN 13501-2 Fire classification of construction products and building elements - Part 2: Classification using data from fire resistance tests, excluding ventilation services

EN 14509:2013 Self-supporting double skin metal faced insulating panels - Factory made products - Specification

Roszkowski P., Sędłak B., 2011. Metodyka badań odporności ogniowej przeszklonych ścian działowych. Świat Szkła, 16(9), p. 59-64.

Sędłak B., Roszkowski P., 2012. Klasyfikacja w zakresie odporności ogniowej przeszklonych ścian działowych. Świat Szkła, 17(7-8), p. 54-59.

Wróblewski B., Borowy A., 2012. Badania i klasyfikacja w zakresie odporności ogniowej ścian $i$ dachów z ptyt warstwowych. Izolacje, 17(7-8) p. 30-34. 